\title{
Highway verges as habitat providers for small mammals in agrosilvopastoral environments
}

\author{
Fernando Ascensão • Anthony P Clevenger • Clara Grilo • \\ Joel Filipe $\cdot$ Margarida Santos-Reis
}

\begin{abstract}
The Mediterranean Basin has an important conservation value given its high biodiversity and high number of endemic species, which have co-existed with human traditional practices for centuries. However, northern areas as the Iberian Peninsula have experienced intensification in livestock production in recent past, with consequent reduction in habitat quality. In this study we assessed the importance of fenced highway verges as habitat for small mammals in Mediterranean agrosilvopastoral landscapes. More specifically, we compared small mammal abundance between highway verges and the adjacent two main land uses ("montado" and open areas); compared the vegetative structure among these land uses; and addressed how vegetation structure influences species occupancy. Thirty-six sites were sampled in agrosilvopastoral system areas in southern Portugal (sampling effort 8,840 trap-nights). A total of 351 individuals from target species
\end{abstract}

Electronic supplementary material The online version of this article (doi:10.1007/s10531-012-0390-3) contains supplementary material, which is available to authorized users.

F. Ascensão (\&) · C. Grilo · J. Filipe · M. Santos-Reis

Departamento de Biologia Animal, Faculdade de Ciências, Centro de Biologia Ambiental, Universidade de Lisboa, Edifício C2-5², 1749-016 Lisbon, Portugal

e-mail: fernandoascensao@gmail.com

C. Grilo

e-mail: claragrilo@ua.pt

J. Filipe

e-mail: joelfsfilipe@fc.ul.pt

M. Santos-Reis

e-mail: mmreis@fc.ul.pt

F. Ascensão · A. P. Clevenger

Western Transportation Institute, Montana State University, P.O. Box 174250, Bozeman, MT 59717, USA

e-mail: apclevenger@gmail.com

C. Grilo

Departamento de Biología de la Conservación, Estación Biológica de Doñana (EBD-CSIC),

Calle Américo Vespucio s/n, 41092 Seville, Spain 
were captured: 157 wood mice (Apodemus sylvaticus), 95 western Mediterranean mice (Mus spretus) and 99 greater white-toothed shrews (Crocidura russula). Capture-markrecapture analyses were performed to estimate population size. Our data suggests that fenced highway verges promote better vegetative structure conditions which in turn favor a higher animal abundance therein. We suggest the adoption of management practices to increase the height and cover of herbaceous and shrub layers in road verges, together with creating grazing controlled areas in highway vicinity, particularly in "montado" patches, linked by vegetated linear features. This would increase habitat and refuge for a large numbers of species, including small mammals, and thus benefiting the trophic chain and the whole agrosilvopastoral system.

Keywords Mediterranean - Iberia Peninsula - Montado woodlands · Road ecology · Capture-mark-recapture $\cdot$ Apodemus sylvaticus $\cdot$ Mus spretus $\cdot$ Crocidura russula

\section{Introduction}

The Mediterranean Basin has a worldwide recognized conservation value, mostly due to exceptionally high floristic species richness and a high proportion of endemic species (Myers et al. 2000). Although having successfully co-existed with human traditional practices for centuries, Mediterranean ecosystems are experiencing increasing reduction in habitat quality in recent years due to the intensification of livestock production (Blondel et al. 2010). This is particularly true in the Iberian Peninsula (Donald et al. 2002; Meeus 1993; Reino et al. 2010).

The main effects of intensive livestock production is overgrazing and soil degradation due to trampling (Ferreira 2000; Pinto-Correia and Mascarenhas 1999; Torre et al. 2007), where the understory structure is often reduced to bare ground devoid of vegetation (Castro and Freitas 2009; Ibáñez et al. 2007; Puerto et al. 1990). Overgrazing and soil trampling may affect small mammal communities (Eccard et al. 2000; Gibson et al. 1992; Gonçalves et al. 2011; Milchunas et al. 1998), by reducing food resources and making soils more compact and less suitable for building and maintaining burrow systems (Bilotta et al. 2007). Additionally, overgrazing can limit vegetation cover, which in turn will increase the exposure to predators (e.g. Torre et al. 2007).

It has been argued that within intensive agricultural landscapes, the conservation of linear features such as hedgerows and field margins play a critical role in maintaining biodiversity. Due to their spatial and structural characteristics, these linear vegetative features provide habitat and refuge for large numbers of mammal species (Alain et al. 2006; Gelling et al. 2007; Stoate et al. 2001; Tattersall et al. 2002). Moreover, as they function as natural corridors, hedgerows and similar habitat elements improve the structural connectivity within landscapes (Bennett et al. 2006) for these species.

The potential conservation value of road verges has also been recognized for decades (e.g. Way 1977). Similar to hedgerows and field margins, road verges are known to be important refuge habitats for many small-sized vertebrate and invertebrate species, including ants (Tshiguvho et al. 1999), butterflies (Saarinen et al. 2005), bees (Hopwood 2008), beetles (Noordijk et al. 2009); birds (Meunier et al. 2000) and small mammals (Bellamy et al. 2000; Oxley et al. 1974; Sabino-Marques and Mira 2011). Road verges may also function as corridors linking habitat patches for many wildlife species (Bennett 1990; Doncaster et al. 2001; Huijser and Clevenger 2006). 
In the Iberian Peninsula highway verges may play an important role as habitat providers for small mammals in agrosilvopastoral habitats. In both Portugal and Spain highways are fenced to mark the boundary between highway right-of-way and adjacent lands and to prevent livestock from accessing the highway proper. This separation often results in roadside verges with lush ungrazed vegetation that may offer cover from predators. Because highways are widespread and expanding, verge management and conservation may help improving population connectivity and long-term viability in human-dominated landscapes (Huijser and Clevenger 2006). However, there is a lack of information regarding the importance of fenced highway verges for small mammal species, including for agrosilvopastoral landscapes in the Mediterranean region.

Highway verge management may be particularly important for small mammals and thus for local biodiversity. Small mammals are situated mid-way along the food chain (e.g. Golley 1960), playing an important role in seed dispersal and controlling invertebrates (Montgomery and Montgomery 1990; Watts 1968). Further, they are an important food source for birds of prey and carnivores (Askew et al. 2007; Virgós et al. 1999), including threatened species such as European wildcat (Felis silvestris) (Moleón and Gil-Sánchez 2003; Sarmento 1996). Hence, small mammals are key organisms in the trophic chain and their abundance and distribution can influence the population dynamics of both prey and predators along transportation corridors (Hanski et al. 2001; Meunier et al. 2000; Mortelliti and Boitani 2008).

The purpose of our study was to assess the importance of fenced highway verges as habitat providers for small mammals. Specifically we addressed (i) whether there were differences between the relative abundance of small mammals living in highway verge habitat and two distinct but predominant adjacent habitat types ("montado" and open areas); (ii) whether small mammal abundance in highway adjacent habitat types ("montado" and open areas) is similar to the one found in verge areas; (iii) whether vegetative structure (height and cover) in highway verges differed from the two main habitat types; and (iv) what effect vegetative structure may have on species occupancy. We focused on the three most abundant surface-dwelling species in our study area: wood mouse (Apodemus sylvaticus, 1758), western Mediterranean mouse (Mus spretus, 1883) and greater white-toothed shrew (Crocidura russula, 1870). For simplicity, greater whitetoothed shrew will be designated as "shrew" hereafter.

We expect highway verges to be an important habitat for these species, expressed by higher abundances in highway verges relative to non-highway sites. Moreover, we expect higher vegetation structure in highway verges, which may be positively related with species occupancy. Our study should therefore be of interest for conservation biologists and transportation planners seeking to understand species-roadway interactions and to find solutions for conservation and protection of wildlife communities in increasingly developed mediterranean landscapes.

Materials and methods

Study area

The study area was located in the Alentejo region of southern Portugal, within $38^{\circ} 38^{\circ} \mathrm{N}$, $8^{\circ} 34^{\circ} \mathrm{W}$ and $37^{\circ} 55^{\circ} \mathrm{N}, 8^{\circ} 12^{\circ} \mathrm{W}$ (Fig. 1). Highway verge habitat was studied in two fourlane highways: A2 and A6; opened to traffic in 1998 and 1995, respectively. Within the highway verge we differentiated the vegetated central median located between highway 
Fig. 1 Location of the study area in the Iberian Peninsula and the sampling sites in the study area. Site types are represented as follows: black circles are highway sites surrounded by "montado" areas; black squares are sites in "montado" areas; white circles are highway sites surrounded by open areas; and white squares are sites in open areas. "Montado" and open areas are represented by dark grey and light grey, respectively. Other land uses are represented in white. Black lines are highways (see Supplementary material for a KML file with site locations)

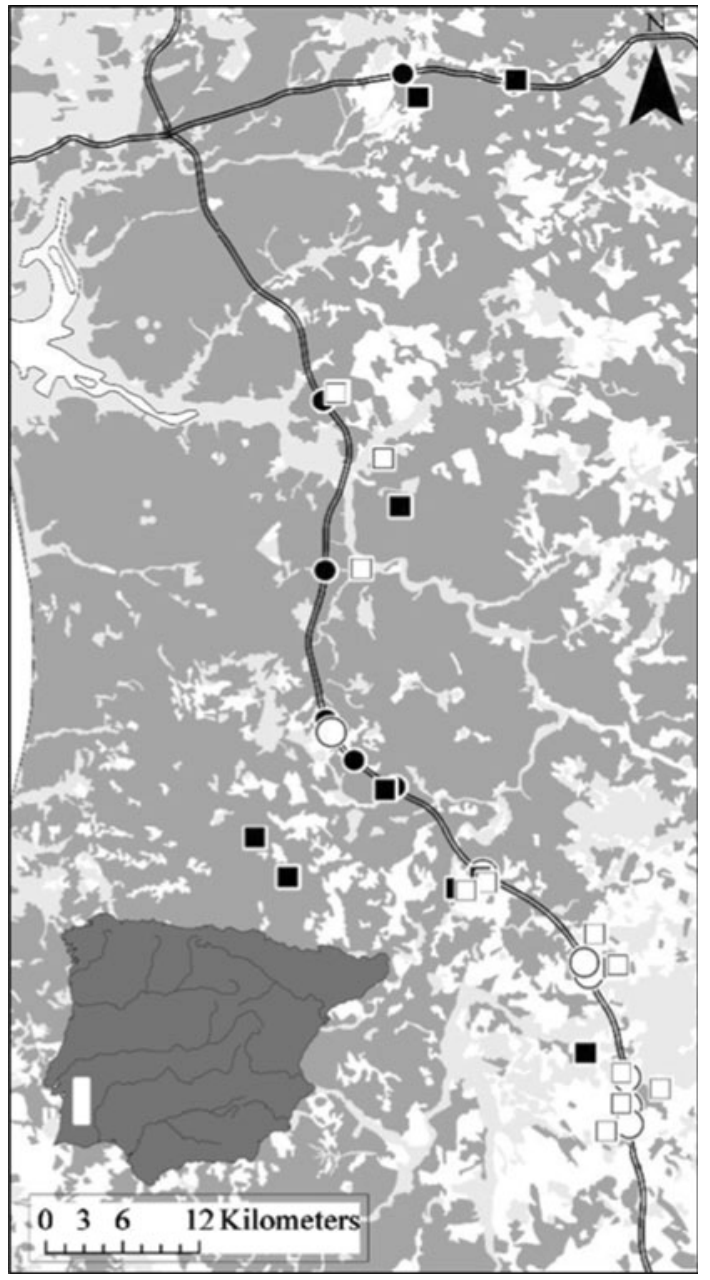

lanes and the vegetated highway margin. Central median width was ca. $5 \mathrm{~m}$ while the highway margin width ranged from 16 to $30 \mathrm{~m}$. The fencing follows the outermost side of margin. During the sampling period (March to May of 2008), the mean nighttime traffic volume (2,100-0,600 h) was $242 \pm 301$ (A2) and $163 \pm 163$ (A6) vehicles per hour (BRISA highway enterprise database).

Land use across study area is mainly represented by "montado" and open habitats. "Montado" is a traditional Mediterranean agrosilvopastoral system (Aronson et al. 2009; Blondel et al. 2010), mostly concentrated in Portugal and Spain (where it is called “dehesa”), covering over three million ha in the Iberian Peninsula (Blondel et al. 2010; Gaspar et al. 2007; Moreno and Pulido 2008). These areas are covered by scattered trees in varying densities, mainly dominated by cork oak (Quercus suber) and holm oak (Q. ilex), superimposed to a mosaic of crops, grassland, fallow lands, shrubland, and extensive animal grazing and cultivation (Pinto-Correia and Mascarenhas 1999). Shrubs are dominated by Cistus, Erica, Lavandula, and Ulex sp. Amid "montado" patches there are areas devoid of trees that are used for crops or left fallow, hereafter referred as open habitats. 
According to the Iberian Climate Atlas (AEMET-IM 2011), across the entire study area the climate is temperate (the coldest months are between 0 and $18{ }^{\circ} \mathrm{C}$ ), with a dry period in summer which is classified as hot (average temperature in the hottest month above $22{ }^{\circ} \mathrm{C}$ ) or temperate (average temperature in the hottest month below or equal to $22^{\circ} \mathrm{C}$, and with 4 months or more with average temperatures above $10{ }^{\circ} \mathrm{C}$ ).

\section{Small mammal sampling}

We quantified the target species abundance in highway verges within pastured "montado" and open habitats and in non-highway sites (pure "montado" and open areas). Our sampling design consisted of four different sampling site types: (1) highway verges surrounded by "montado" (HWY_MONT; n = 7); (2) highway verges surrounded by open areas (HWY_OPEN; $n=7$ ); (3) pure “montado" areas (MONT; $n=11$ ); and (4) homogeneous open areas (OPEN; $n=11$ ). Prior to sampling, we identify 30 potential sampling sites for each site type. For non-highway sites, we only considered areas exhibiting frequent overgrazing signs: livestock manure, patches of bare ground without plant regeneration and, where present, young trees broken. The sampling sites were then randomly chosen within this set of locations. To minimize spatial autocorrelation sites were located at least $500 \mathrm{~m}$ apart (neighborhood distance: mean $=1,702 \pm 1,654 \mathrm{~m}$; $\max =7,110 \mathrm{~m}$ ).

Highway sites were sampled using three parallel trap-lines: one along the highway central median (median), one along the highway verge (margin) and one outside the highway area (outer). outer trap-lines were set parallel to the highway and at a distance equivalent to the highway pavement width (ca. $25 \mathrm{~m}$ ) (Fig. 2). Data from this trap-line was used to infer if the expected positive verge effect extends to bordering areas. Highway fencing is located in the outermost margin side. Between margin and main land use ("montado" or open habitats), there is a mowed strip with ca. $5 \mathrm{~m}$, for fire prevention. For non-highway sites (MONT and OPEN), we set two parallel trap-lines, also ca. $25 \mathrm{~m}$ apart. In all cases, each trap-line contained 20 baited Sherman ${ }^{\mathrm{TM}}$ live traps, $10 \mathrm{~m}$ apart.

The first four sampled sites were surveyed for six consecutive nights, but for logistical reasons, remaining sites were sampled for five nights. This was supported by inspecting the capture-recapture history, in which the majority of new captures occurred within the first three nights (see Fig. A in supplementary material). Site survey order was randomly assigned and four sites where sampled simultaneously.

Captured animals were marked with a fur cut mark, sexed, weighed and released at capture site. This procedure took approximately 5 min per individual. Capture procedures

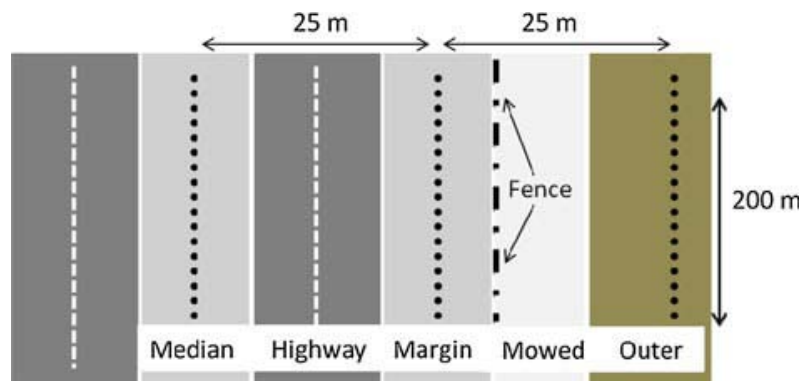

Fig. 2 Trap-lines location in highway sites (median, margin and outer). Outer line was set at the same distance as median-margin line distance (ca. $25 \mathrm{~m}$ ). Adjacent to the highway limit there is a mowed strip for fire prevention. Highway fence is placed between margin and mowed areas. Distances are not equally scaled 
and animal handling were in conformity with Portuguese Biodiversity Conservation Institute directives (ICNB, Instituto da Conservação da Natureza e Biodiversidade).

\section{Vegetative structure characterization}

Species of herbaceous and shrub layers in verges may often be similar to ones found in adjacent areas (Santos et al. 2007; Tanghe and Godefroid 2000), although several exotic species are regularly planted in highway verges (Forman and Alexander 1998). We were mainly concerned with vegetative structure (height and cover), as this may be a limiting factor for small mammals' persistence (Muñoz et al. 2009; Torre et al. 2007), even if provided by exotic species. Therefore, vegetation height and cover of both the herbaceous and shrub layers were quantified. These four variables were measured at all four site types by the same two observers. Around each trap location (1 m radius) we visually estimated the mean height and cover of each vegetation layer. The estimation for each trap was a consensus between the two observers. Previous to site categorization, several trials were performed and results discussed within the fieldwork team. Height estimates were categorized in $10 \mathrm{~cm}$ classes. For cover we classified the layers at each trap location as one of four classes (0-25\%, 25-50 \%, 50-75\% and 75-100\%).

\section{Data analysis}

Small mammals’ population size

In order to evaluate if our sampling design could provide an accurate representation of population size $(\mathrm{N})$, and hence reliable species abundances, we used capture-markrecapture $(\mathrm{CMR})$ analyses to estimate the population size $\left(\mathrm{N}_{\text {est }}\right)$ of each species. For sampling sites with two or more captured individuals (per species), we estimated $\mathrm{N}_{\text {est }}$ using the 'Rcapture' R package (Baillargeon and Rivest 2009). This package uses Poisson regressions to estimate parameters in a CMR experiments and produces maximum likelihood estimates of the loglinear models' parameters. $\mathrm{N}_{\mathrm{est}}$ is then derived from these loglinear parameters (Baillargeon and Rivest 2009).

We assumed that all populations in sampled sites were "closed", which indicates that neither mortality nor immigration occurred during the sample period. Hence, the size of a closed population does not vary during the experiment. This assumption is reasonable for capture-recapture experiments held over a short period of time. We used a bias correction (function 'closedp.bc') for small samples to improve estimations and stabilize the standard errors estimates (Baillargeon and Rivest 2009); and assumed equal probabilities of capture during the experiment. Because small samples often lead to large standard errors, we considered only estimates where the coefficient of variation (standard deviation of $\mathrm{N}_{\text {est }}$ divided by $\mathrm{N}_{\text {est }}$ ) was lower than $30 \%$ (Rivest personal communication). One limitation of 'Rcapture' is that it does not handle trap deaths. Therefore we remove from analysis all death records (wood mouse $n=3$; western Mediterranean mice $n=2$; and shrew $n=4$ ). The number of captures and $\mathrm{N}_{\mathrm{est}}$ were compared by Wilcoxon paired test.

Small mammals’ abundance and vegetative structure comparisons among sites

We used the minimum number of live small mammals per sampling effort as an index of abundance. We compared small mammal abundance and the vegetation structure for each 
of the four sampling site types. We did not consider the data from the outer trap-line of highway sites in these comparisons, as we were primarily interested in relating the species information and the vegetation structure within the highway right-of-way with the two land use types. We then compared the abundance among the three trap-lines for highway sites (median, margin and outer).

We used $\mathrm{a} \mathrm{v}^{2}$ contingency test to compare the number of small mammals trapped in each sampling site type by sex. Because of the small sample size we pooled all trap-line data, except for wood mouse in HWY_MONT and for shrew in HWY_OPEN. For these, comparisons for each trap-line were also performed. In all cases, $\mathrm{p}$ values were computed by Monte Carlo simulations using 2,000 replicates (Hope 1968).

In all comparisons, and due to non-normality of data and small sample size, we used Kruskal-Wallis tests and subsequent non-parametric multiple comparisons using the $\mathrm{R}$ package 'agricolae' (Mendiburu 2010). Because sequential Bonferroni correction of significance levels (Holm 1979) can inflate the Type I error rate (Moran 2003), we report unadjusted significance values, highlighting those that remain significant after correction (see Tables A, B, C, D in supplementary material).

Relating small mammals occupancy with vegetative structure

We modeled species occupancy according to vegetative structure at the trap level. For each species, all traps were coded as 'presence' if at least one individual was trapped during the sampling period and 'absence' otherwise, which was used as the response variable. Generalized linear mixed models (GLMMs, Breslow and Clayton 1993) with logistic link, a binomial error distribution and Laplace approximation were built using the $\mathrm{R}$ package 'Ime4' (Bates and Maechler 2010). The four vegetation variables (cover and height of herbaceous and shrub layers) were used in models as fixed effects and site identification nested in site type was used as random effect. Vegetation cover variables were treated as equally spaced ordinal variables.

Before model building, we checked for collinearity between vegetation variables as it may inflate the variances of the parameter estimates, by verifying the variance inflator factor (Graham 2003). We also checked for spatial autocorrelation by plotting the residuals of each GLMM models containing all uncorrelated explanatory variables in spline correlograms (Bjørnstad 2009; Bjørnstad and Falck 2001).

Alternative models using all possible combinations of variables were built and ranked according to the Akaike Information Criterion adjusted for small sample sizes (AIC $_{c}$ (Burnham and Anderson 2002). The goal of building models using all variables' combinations was to infer the relative importance of each vegetation predictor on species presence. We computed the Akaike weights $\left(\mathrm{w}_{\mathrm{i}}\right)$ of all models and for each variable we summed the weights of those models where the variable was included (Burnham and Anderson 2002). $\mathrm{AIC}_{\mathrm{c}}$ and $\mathrm{w}_{\mathrm{i}}$ were computed using the R package 'MuMIn' (Barton 2011). Because cover attributes were treated as ordinal variables, 'MuMIn' does not report the models' coefficients for these variables. Instead, the package highlight the use of these variables in the models with a "?". Therefore, ad hoc inspections were performed to verify the trend effect of herbaceous and shrub cover in species presence: all models with $\mathrm{AIC}_{\mathrm{c}} \backslash 3$ containing these variables were rerun and the coefficients for the ordinal variables were checked. No interaction terms were included due lack of model convergence. All statistical computation and plots were made in $\mathrm{R}$ environment (R Development Core Team 2010). 
Results

Population size

We captured 355 different individuals comprising 157 wood mice, 95 western Mediterranean mice and 99 shrews in a total sampling effort of 8,840 trap-nights. Incidental records included three Cabrera's voles (Microtus cabrerae) at highway sites and one black rat (Rattus rattus) at one open site. We were able to estimate population size at 19 sites, of which 10 were for wood mouse, five for western Mediterranean mouse and four for shrew. Estimates ranged from two to 29 individuals per site for wood mouse; four to 39 individuals for western Mediterranean mouse; and four to 20 individuals for shrew (Table 1). Estimated values were not significantly different than the observed results (Wilcoxon pair test, $\mathrm{W}=0$, p value $\backslash 0.001$ ). Hence, we consider that nearly all individuals in sampled sites were captured and thus computed abundances were reliable.

Abundance and vegetation structure comparisons among sites

Overall there was a higher abundance of small mammals in highway sites compared to non-highway sites; with highway sites surrounded by “montado” (HWY_MONT) having the highest abundance values (Fig. 3; Table A in Supplementary material). Wood mice were mainly captured in HWY_MONT, whereas few captures occurred in the other sites. We captured a low number of wood mice and recorded no captures of western Mediterranean mice at "montado" sites (MONT), although this latter species was captured in HWY_MONT. As for shrews, we found a higher abundance in both HWY_MONT and highway sites surrounded by open areas (HWY_OPEN).

Regarding the number of captures by trap-line at the highway sites, the majority of individuals were captured in the margin line followed by the median trap-line (Fig. 4; Table B in Supplementary material). We recorded a small number of captures in the outer trap-line in

Table 1 Estimates of population size from CMR data by species and sampling site type, assuming closed population scenario

Sampling sites consisted in highway sites surrounded by "montado" areas (HWY_MONT), highway sites surrounded by open areas (HWY_OPEN), pure "montado" areas (MONT) and pure open areas (OPEN)

$\mathrm{N}$ minimum number alive, $\mathrm{N}_{\mathrm{est}}$ estimated population size for each site, SE standard error of $\mathrm{N}_{\mathrm{est}}$

\begin{tabular}{|c|c|c|c|c|c|}
\hline Species & Site type & Site & $\mathrm{N}$ & $\mathrm{N}_{\mathrm{est}}$ & SE \\
\hline \multirow[t]{8}{*}{ Wood mouse } & \multirow[t]{5}{*}{ HWY_MONT } & B1 & 25 & 30.1 & 3.2 \\
\hline & & B2 & 25 & 27.5 & 2.0 \\
\hline & & B101 & 17 & 20.6 & 2.8 \\
\hline & & B102 & 19 & 20.0 & 1.2 \\
\hline & & B4 & 22 & 23.6 & 1.5 \\
\hline & HWY_OPEN & B3 & 9 & 10.7 & 1.9 \\
\hline & \multirow[t]{2}{*}{ MONT } & M1 & 10 & 14.3 & 3.7 \\
\hline & & M100 & 4 & 4.2 & 0.4 \\
\hline \multirow{4}{*}{$\begin{array}{l}\text { Western Mediterranean } \\
\text { mouse }\end{array}$} & HWY_MONT & B4 & 3 & 3.6 & 1.1 \\
\hline & HWY_OPEN & B5 & 19 & 27.8 & 5.6 \\
\hline & \multirow[t]{2}{*}{ OPEN } & E5 & 14 & 21.2 & 5.3 \\
\hline & & E8 & 31 & 38.7 & 4.2 \\
\hline \multirow{4}{*}{$\begin{array}{l}\text { Greater white-toothed } \\
\text { shrew }\end{array}$} & HWY_MONT & B4 & 3 & 3.6 & 1.1 \\
\hline & HWY_OPEN & B5 & 19 & 27.8 & 5.6 \\
\hline & \multirow[t]{2}{*}{ OPEN } & E5 & 14 & 21.2 & 5.3 \\
\hline & & E8 & 31 & 38.7 & 4.2 \\
\hline
\end{tabular}



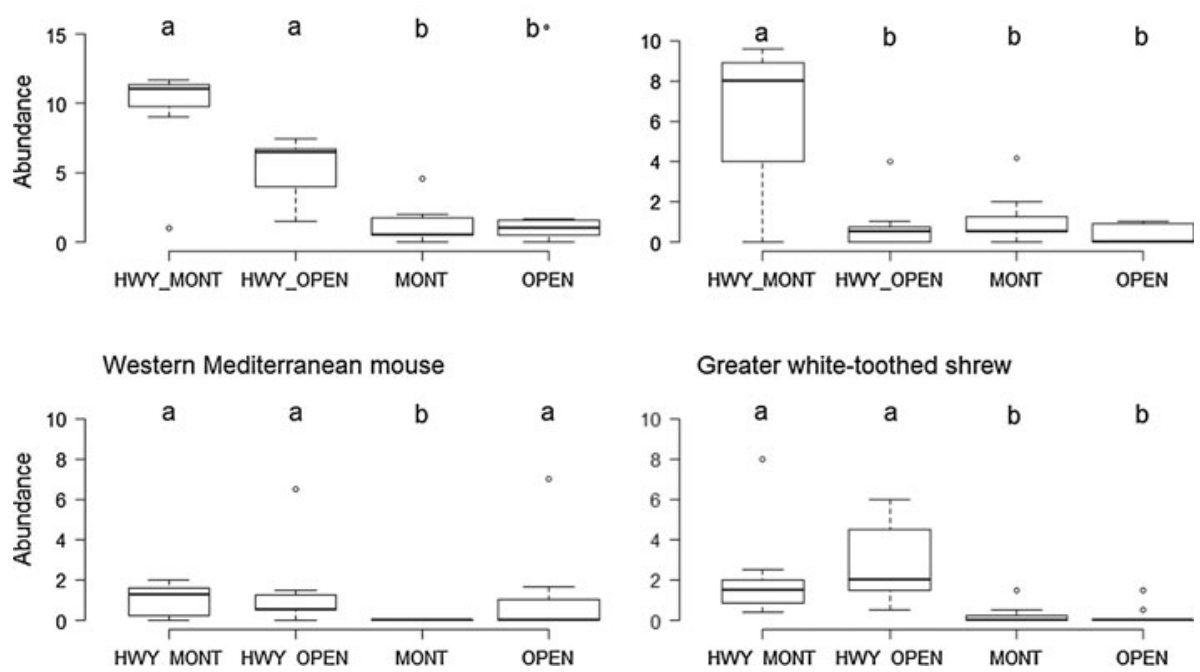

Fig. 3 Boxplots of small mammal abundance for each of the four sampling site types. Box upper and lower limits represent the interquartile range (IQR), thick line is the median and "whiskers" are the $\pm 1.59 \mathrm{IQR}$. Circles are outliers. Sampling sites consisted in highway sites surrounded by "montado" areas (HWY_MONT), highway sites surrounded by open areas (HWY_OPEN), “montado” areas (MONT) and open areas (OPEN). Abundance refers to minimum number of individuals alive per sampling effort. Same letters indicate no significant differences $(\mathrm{p} \backslash 0.05)$ between sites. Adjusted $\mathrm{p}$ values from sequential Bonferroni correction are available in Table A of Supplementary material

HWY_MONT. The abundance of the three species combined was significantly lower in the outer line than the median line $(\mathrm{K}=11.2$, $\mathrm{p}$ value $=0.035)$. As for wood mouse only, its abundance in the outer line was marginally significantly lower from the verge line $(\mathrm{K}=6.5$, $\mathrm{p}$ value $=0.051$ ), while for western Mediterranean mouse it was marginally significantly lower from the median line $(\mathrm{K}=4.9$, $\mathrm{p}$ value $=0.049)$. Nevertheless, all these comparisons are not significant if the sequential Bonferroni correction is applied (alpha $=0.017$ ). Therefore, the species abundance in highway bordering areas seem to be similar than the one found in verges.

We found no significant differences in sex ratios, except for wood mouse in MONT where a higher number of males were captured $\left(\mathrm{v}^{2}=6.5, \mathrm{n}_{1}=5, \mathrm{n}_{2}=17, \mathrm{p}\right.$ value $\left.=0.020\right)$, and for shrew in HWY_OPEN where a higher number of females were captured $\left(v^{2}=5.3\right.$, $\mathrm{n}_{1}=32, \mathrm{n}_{2}=16, \overline{\mathrm{p}}$ value $=0.032$ ). This latter was due a higher number of captured females in the median line $\left(\mathrm{v}^{2}=7.1, \mathrm{n}_{1}=14, \mathrm{n}_{2}=3\right.$, $\mathrm{p}$ value $\left.\backslash 0.015\right)$.

Vegetative structure differed significantly among site types (Fig. 5; Table C in Supplementary material). The only pairs of site types for which we found no significant differences after the sequential Bonferroni correction were in HWY_OPEN - MONT (shrub height); HWY_OPEN - MONT (herbaceous height), and HWY_MONT - MONT (herbaceous height). Overall we found taller and denser shrub layers in highway sites, while herbaceous cover and height were higher in non-highway open sites (Fig. 5).

Relating small mammals’ occupancy with vegetative structure

All variables considered in the analysis showed an inflation factor below 2.0, suggesting that collinearity was negligible (Chatterjee and Price 1991), and therefore the four 


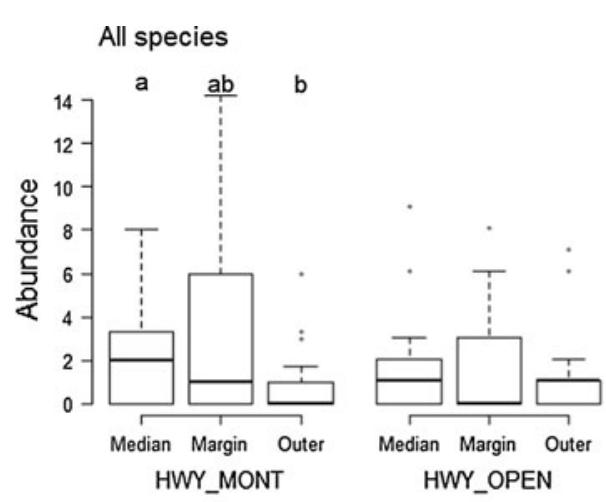

Wood mouse

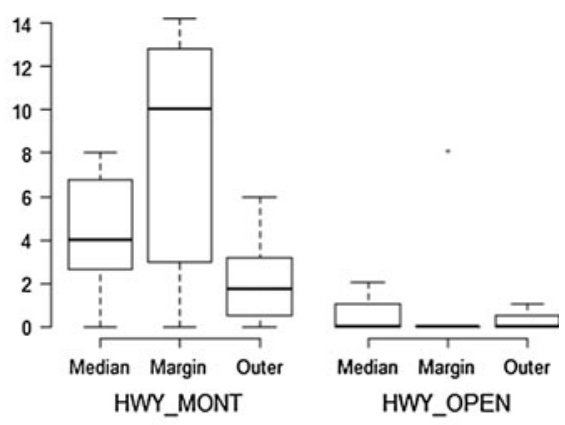

Western Mediterranean mouse

Greater white-toothed shrew
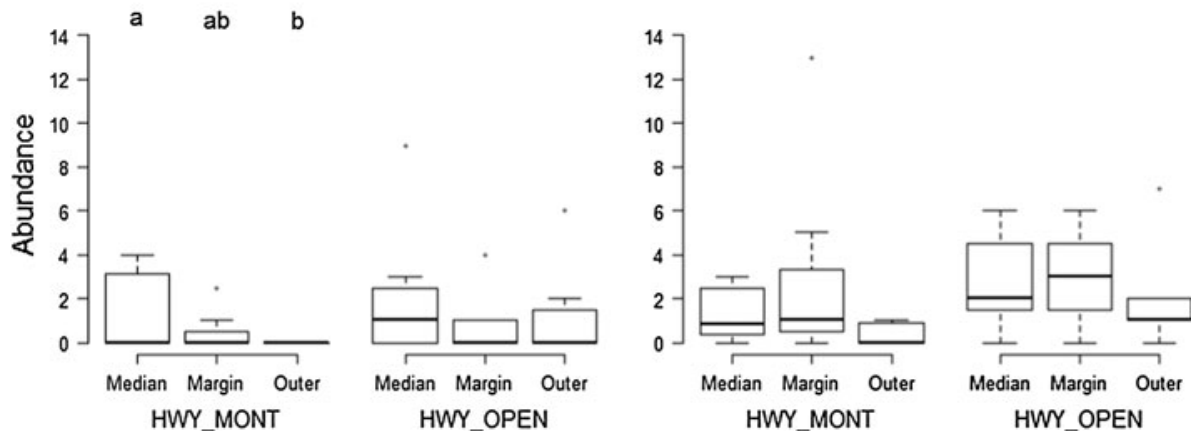

Fig. 4 Boxplots of small mammal abundance in highway sites by trap-line (median, margin and outer). Box upper and lower limits represent the interquartile range (IQR), thick line is the median and "whiskers" are the \pm 1.59 IQR. Circles are outliers. Highway sites were surrounded by "montado" areas (HWY_MONT) or open areas (HWY_OPEN). Abundance refers to minimum number of individuals alive per sampling effort. Where indicated, same letters indicate no significant differences $(p \backslash 0.05)$ between sites. None of the p values remained significant after sequential Bonferroni correction (Table B in Supplementary material)

predictors were retained for further analyses. We found no signs of autocorrelation for any species after fitting full models' residuals in correlograms (Fig. A in Supplementary material).

The most parsimonious model for explaining variations in wood mouse presence at the trap level was one in which shrub height and cover were the predictor variables. This model accounted for $35 \%$ of the Akaike weights $\left(\mathrm{w}_{\mathrm{i}}\right)$ in the model set. According to $\mathrm{DAIC}_{\mathrm{c}}$ ranking, the next four models had $\mathrm{DAIC}_{\mathrm{c}} \backslash 3$, indicating their similarity with the best model, all including shrub height. These five models had a cumulative $\mathrm{w}_{\mathrm{i}}$ of 0.93 (Table 2). For western Mediterranean mouse we obtained three models with $\mathrm{DAIC}_{\mathrm{c}} \backslash 3$, where the most parsimonious included herbaceous height only and had $\mathrm{w}_{\mathrm{i}}$ of 0.47 . The three models accounted for $85 \%$ of $\mathrm{w}_{\mathrm{i}}$. As for shrew, the most parsimonious model was also the only one with $\mathrm{DAIC}_{\mathrm{c}} \backslash 3$, and included shrub height and herbaceous height, accounting for $70 \%$ of $\mathrm{w}_{\mathrm{i}}$.

Coefficients of ordinal variables revealed a linear trend between cover and the presence of species in all cases. From all model combination we obtained the AIC $_{c}$ weight for each vegetation cover attribute. Accordingly, the presence of wood mice was mainly related to tall and dense shrubs; western Mediterranean mice were associated with sites with tall 

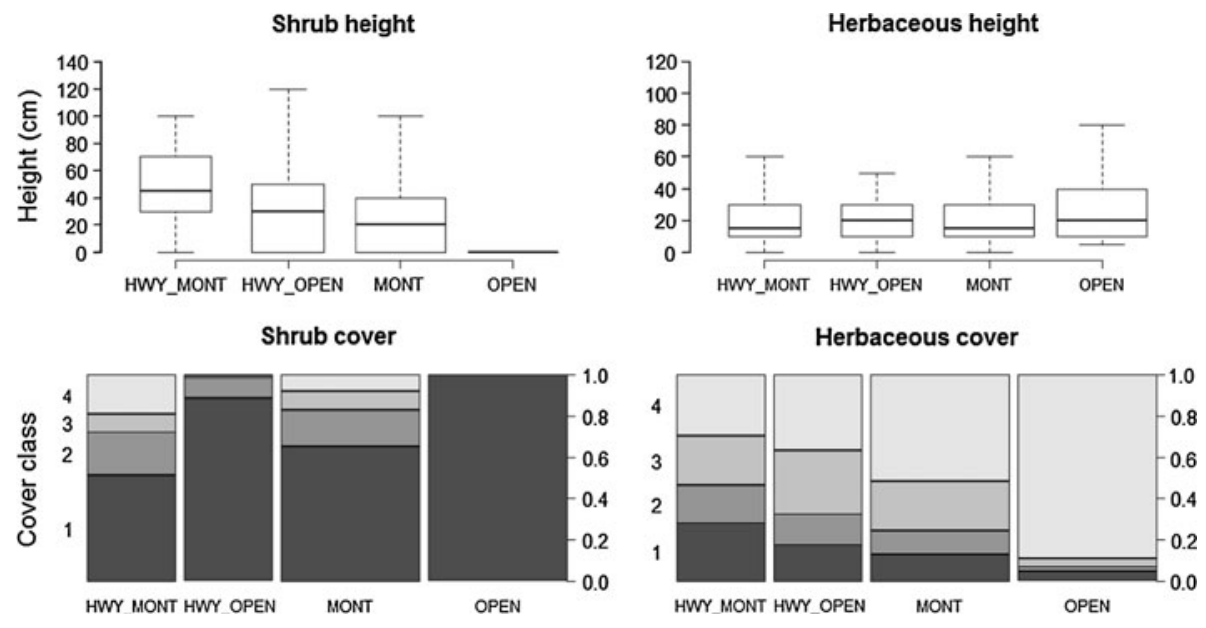

Fig. 5 Vegetation structure characteristics. Upper graphs boxplots of shrub and herbaceous height. Boxplot upper and lower limits represent the interquartile range (IQR), thick line is the median and "whiskers" are the $\pm 1.59 \mathrm{IQR}$. Lower graphs mosaic plots of shrubs and herbaceous layers, by site type. Cover is expressed in four classes where 1 represents a low cover and 4 represents high cover. The heights of the bars in cover plots correspond to the relative frequencies of each class in each site type. Secondary y axis represents the cumulative proportion of each class

herbaceous vegetation, while shrews were associated with tall shrubs and herbaceous vegetation (Table 3).

\section{Discussion}

Our findings show that highway verges can be important habitat for small mammals within intensively livestock used Mediterranean landscapes. We confirmed that highway verges are capable of supporting a relatively high abundance of small mammals, in most cases higher than pure "montado" and open sites. This was particularly true for wood mice and shrews. Our results are in agreement with previous studies that have reported higher abundances of small mammals in highway verges compared to surrounding areas (e.g. Adams and Geis 1983; Bellamy et al. 2000; Meunier et al. 1999). Also, together with observed captures of the endangered Cabrera vole in our study sites, we were able to confirm that verges are not only used by multiple species, but also by those of high conservation concern (Santos et al. 2007).

We found no differences in sex ratios for highway sites except for shrews. However, we take this result with caution, as it can be difficult to identify correctly the sex of shrews due the lack of sexual dimorphism (see Searle 1985). Thus, considering only the results from wood mouse and western Mediterranean mouse, the presence of the highway does not induce changes in sex ratios. The data further shows that within intensively used areas, highway verges should be included in management plans toward conservation of biodiversity and the whole agrosilvopastoral system.

Being the first study in a Mediterranean environment regarding highway verge importance for small mammals, our results suggest that the higher abundance here found was related to the presence of fences. Fencing converts verges into grazing exclosure areas, 
Table 2 GLMMs describing target species presence with shrub and herbaceous height and density (fixed effects), at the trap level

\begin{tabular}{|c|c|c|c|c|c|c|c|c|}
\hline Interc & $\begin{array}{l}\text { Shrub } \\
\text { height }\end{array}$ & $\begin{array}{l}\text { Herbaceous } \\
\text { height }\end{array}$ & $\begin{array}{l}\text { Shrub } \\
\text { cover }\end{array}$ & $\begin{array}{l}\text { Herbaceous } \\
\text { cover }\end{array}$ & LL & $\mathrm{k}$ & DAIC $_{c}$ & $\mathrm{w}_{\mathrm{i}}$ \\
\hline \multicolumn{9}{|c|}{ Wood mouse } \\
\hline-4.1 & 0.023 & & 0.764 & & -359.4 & 7 & 0.0 & 0.35 \\
\hline-4.6 & 0.027 & & & & -362.9 & 4 & 1.0 & 0.21 \\
\hline-4.3 & 0.023 & 0.007 & 0.793 & & -359.1 & 8 & 1.4 & 0.17 \\
\hline-4.2 & 0.024 & & 0.476 & 0.990 & -357.6 & 10 & 2.5 & 0.10 \\
\hline-4.7 & 0.027 & 0.006 & & & -362.7 & 5 & 2.6 & 0.10 \\
\hline-3.8 & (null) & & & & -384.5 & 3 & 42.3 & 0.00 \\
\hline \multicolumn{9}{|c|}{ Western Mediterranean mouse } \\
\hline-5.6 & & 0.029 & & & -234.7 & 4 & 0.0 & 0.47 \\
\hline-5.7 & 0.004 & 0.029 & & & -234.5 & 5 & 1.7 & 0.20 \\
\hline-5.8 & & 0.026 & & 0.841 & -232.6 & 7 & 1.9 & 0.18 \\
\hline-5.1 & (null) & & & & -241.9 & 3 & 12.4 & 0.00 \\
\hline \multicolumn{9}{|c|}{ Greater white-toothed shrew } \\
\hline-5.5 & 0.011 & 0.042 & & & -313.6 & 5 & 0.00 & 0.70 \\
\hline-3.9 & (null) & & & & -326.5 & 3 & 21.73 & 0.00 \\
\hline
\end{tabular}

Cover variables were treated as ordinal. Shown are model estimates for each variable, log-likelihood (LL), number of parameters $(\mathrm{k})$, change in Akaike information criterion with correction for small sample sizes $\left(\right.$ DAIC $\left._{c}\right)$, AIC $_{c}$ weight $\left(\mathrm{w}_{\mathrm{i}}\right)$. Models are ranked according to the DAIC ${ }_{\mathrm{c}}$. Only models with $\mathrm{DAIC}_{\mathrm{c}} \backslash 3$ are shown, together with the null model. All models for the three species are listed in Table D in supplementary material

Table 3 Relative importance of vegetation variable to explain species presence at the trap level

\begin{tabular}{lllll}
\hline Species & Shrub height & Herbaceous height & Shrub cover & Herbaceous cover \\
\hline Wood mouse & 1.00 & 0.31 & 0.67 & 0.16 \\
Western Mediterranean mouse & 0.31 & 1.00 & 0.05 & 0.29 \\
Greater white-toothed shrew & 0.91 & 1.00 & 0.19 & 0.07
\end{tabular}

For each variable, the Akaike weights $\left(\mathrm{w}_{\mathrm{i}}\right)$ of the models where the variable was present were summed.

Higher values represent higher importance

allowing good vegetative structure to develop. In turn, the vegetation provides cover protection from predators and important food and shelter resources for small mammals. There is an extensive literature showing that cover is a limiting factor for small mammals and required mainly for predator avoidance (Fitzgibbon 1997; Kotler 1997; Longland and Price 1991; Muñoz et al. 2009; Torre et al. 2007). Our results are in agreement with this previous research. All models showed that a higher probability of occupancy of wood mice was related to taller and denser shrub cover. In fact, this species is often found in well conserved and extensively managed "montado" patches (Rosalino et al. 2011) and, according to our surveys, the shrub layer was significantly taller and denser in verges surrounded by "montado" areas, relatively to pure areas themselves. This may explain the higher abundance of this species in highway verges. Likewise, the absence of western Mediterranean mice in "montado" sites and the low number of captures of shrews in "montado" and open areas is probably related to the low vegetative structure there found. 
Shrews are known to respond positively to grassland cover (Rodríguez and Peris 2007) and its highest abundance was recorded in highway verges surrounded by open areas where the herbaceous layer was taller.

Therefore, fenced highways probably make the highway verges an attractive habitat for small mammals, particularly in areas of higher livestock pressure. In fact, vegetation in verges is usually planted or managed in a way to allow their growth for artificial landscaping reasons, with occasional mowing, while in "montado" areas the livestock grazing may significantly reduce the vegetative structure. Traditionally, extensive livestock stocking rates permitted maintaining the shrub and herbaceous layers stable (Moreno and Pulido 2008). However, after Portugal and Spain joined the European Union, the Common Agricultural Policy led to a significant increase in stocking rates (Moreno and Pulido 2008). The livestock numbers reached similar densities to those found in highly productive regions in northern Europe, in spite of the Mediterranean environments being less productive (Campos 2004).

When in high densities, livestock grazing and trampling result in a decrease of vegetative complexity, and thus in a reduction of cover and protection for small mammals. For example, Torre et al. (2007) measured the small mammal abundance, species composition, vegetation structure and soil compaction in 22 plots pertaining to two grazing levels (grazed areas and cattle exclosures) in a Mediterranean landscape. They found that in areas where cattle had been excluded, the vegetation height and density increased and soil compaction decreased, which led to higher small mammal abundance and species richness. The authors concluded that the effect of grazing on small mammal communities was mainly due to reduced food availability and by negative effects of trampling on the suitability of soils for building burrow systems. Other authors also described the negative effects of trampling in soil compaction, with consequent reduction of the available area for building and maintaining stable burrows for small mammals (e.g. Bilotta et al. 2007).

These facts may also explain the different abundance detected in the trap-lines of highway sites. Overall we found a higher abundance of small mammals in the median line and a lower abundance in the outer line, but no pair trap-line comparison remained significant after sequential Bonferroni correction. Although located nearby the verge, outer trap-line traps were within the grazing area, and therefore the vegetative structure could probably offer a low protection for predators. Thus, the median line might provide an extra protection due to its location in between traffic lanes which may limit the incursions of predators such as carnivores (Fahrig and Rytwinski 2009), and therefore allowing for higher small mammal abundances in this line.

Given our results, we suggest that the proper management of highway verge vegetation and the creation of grazing controlled areas nearby the highway might significantly influence the abundance of small mammals, and therefore constitute two important actions aimed to conserve biodiversity and habitats. Transportation agencies generally mow highway verges regardless of the distance from highway edge. We recommend verges continue to be managed for motorist safety objectives, but also that verge margins outside of the "clear zone" (ca. 10-12 m from pavement edge) should be managed to allow taller and denser vegetative structure. Although our target species responded positively to higher vegetative structure, we detected some differences in the relative importance of different height and cover of herbaceous and shrub layers. Therefore, verge management should try to create vegetative structure that is variable in these attributes in order to favor greater biodiversity of small mammal species living there (e.g. creating some spots with taller shrubs and others without shrubs but with a higher and denser grass layer). 
Where applicable, verge management should also be included in broader scale conservation actions away from the highway for protecting connectivity of small mammal populations and their habitat. Several studies demonstrated the positive effects of managed grazing areas in vegetative structure and soil quality, which in turn favored higher small mammal abundance (Eccard et al. 2000; Fitzgibbon 1997; Gelling et al. 2007; Gonçalves et al. 2011; Hayward et al. 1997; Todd et al. 2000). Thus, we suggest creating fenced areas, with very low rates of livestock grazing, within intensive sylviculture production areas. These managed grazed areas could be linked to highway verges through other habitat elements such as vegetated linear features, e.g., hedgerows or riparian areas. The creation of these managed grazing areas and restoration of vegetative linear features could take advantage of European Union agri-environment schemes (Donald and Evans 2006; Kleijn and Sutherland 2003; Whittingham 2007). In subsidy programs, farmers are paid to modify their farming practices to provide environmental benefits, including reduction of livestock farming.

By implementing these practices, we would expect the improvement of the overall landscape connectivity and population persistence of small mammals. In turn, by contributing to the population persistence of these species, these measures will help maintain the equilibrium of the trophic chain and the regeneration of the agrosilvopastoral system. For example, wood mice are an important prey species for top predators, including endangered species such as wildcat (Moleón and Gil-Sánchez 2003; Sarmento 1996), and also several raptor species (Korpimaki and Norrdahl 1991). Wood mice are also important seed dispersers of acorns (Gómez et al. 2008).

In order to implement these two conservation actions, it is important to have an inventory of distribution and quality of vegetative structure and habitat along highway networks in Mediterranean regions of the Iberian Peninsula. This inventory should consider the location and the quality of the vegetation structure of verge habitats occurring in highway corridor and lands adjacent to it, including hedgerows, field margins and riparian areas. A large-scale inventory could be performed with aerial images in a geographic information system, although site-specific management actions would require field verification. With this information, potential sites to implement managed grazing areas could be identified and selected based on proximity and connectivity to highway sections of conservation value.

It should be noted that by increasing the prey density in highway verges, these may attract more predators to the highway corridor. This will in turn increase the risk of predator-vehicle collision, as reported for polecat (Mustela putorius) by Barrientos and Bolonio (2009). However, as suggested by these authors and other studies (e.g. Grilo et al. 2009), by reducing the mesh size of existing highway fencing, particularly in locations where is likely to occur mortality hot-spots (Ramp et al. 2005), it is possible to reduce the access of predators to verge area.

Further study of fenced highway verges, together with grazing exclosure areas connected by natural habitat elements, will help identify the role of managed verges in the conservation of small mammal populations and predators in the Mediterranean agrosilvopastoral system.

Acknowledgments This study was conducted in the framework of a research project under a protocol between BRISA Auto-Estradas de Portugal S. A. and Centro de Biologia Ambiental (BRISA-CBA 2007-2010 - “Eficácia de medidas de minimização dos efeitos negativos das auto-estradas”). Funding was provided by BRISA and Fundação para a Ciência e a Tecnologia with a PhD Grant (F. Ascensão SFRH/BD/ 38053/2007) and a Pos-doc Grant (C. Grilo SFRH/BPD/64205/2009). Special thanks are due to Maria Luz Mathias and Carnivora association for providing us additional the Sherman traps; Dulce Ferreira, Hany 
Alonso, João and Erasmus students Gabi and Zita for the help in collecting data; and John A. Bissonette and two anonymous reviewers for comments on a previous version of this manuscript.

\section{References}

Adams LW, Geis AD (1983) Effects of roads on small mammals. J Appl Ecol 20(2):403-415

AEMET-IM (2011) Iberian Climate Atlas-air temperature and precipitation (1971-2000). AEMET: Agencia Estatal de Meteorología and Instituto de Meteorologia. Spain, Closas-Orcoyen, Madrid

Alain B, Gilles P, Yannick D (2006) Factors driving small rodents assemblages from field boundaries in agricultural landscapes of western France. Landsc Ecol 21(3):449-461

Aronson J, Pereira JS, Pausas JG (2009) Cork oak woodlands on the edge: ecology, adaptive management, and restoration. Island Press, Washington, DC

Askew NP, Searle JB, Moore NP (2007) Agri-environment schemes and foraging of barn owls Tyto alba. Agric Ecosyst Environ 118(1-4):109-114

Baillargeon S, Rivest L-P (2009) Rcapture: loglinear models for capture-recapture experiments. R package version 1.2-0. http://CRANR-projectorg/package=Rcapture. Accessed 1 Jan 2012

Barrientos R, Bolonio L (2009) The presence of rabbits adjacent to roads increases polecat road mortality. Biodivers Conserv 18:405-418

Barton K (2011) MuMIn: multi-model inference. R package version 01321. http:/CRANR-projectorg/ package=MuMIn. Accessed 1 Jan 2012

Bates D, Maechler M (2010) lme4: linear mixed-effects models using S4 classes. R package version 0999375-37. http://CRANR-projectorg/package=lme4. Accessed 1 Jan 2012

Bellamy PE, Shore RF, Ardeshir D, Treweek JR, Sparks TH (2000) Road verges as habitat for small mammals in Britain. Mamm Rev 30(2):131-139

Bennett AF (1990) Habitat corridors and the conservation of small mammals in a fragmented forest environment. Landsc Ecol 4(2):109-122

Bennett AF, Radford JQ, Haslem A (2006) Properties of land mosaics: implications for nature conservation in agricultural environments. Biol Conserv 133(2):250-264

Bilotta GS, Brazier RE, Haygarth PM (2007) The impacts of grazing animals on the quality of soils, vegetation, and surface waters in intensively managed grasslands. Adv Agron 94:237-280

Bjørnstad ON (2009) ncf: spatial nonparametric covariance functions. R package version 11-3. http:// CRANR-projectorg/package=ncf. Accessed 1 Jan 2012

Bjørnstad ON, Falck W (2001) Nonparametric spatial covariance functions: estimation and testing. Environ Ecol Stat 8(1):53-70

Blondel J, Aronson J, Bodiou J-Y (2010) The Mediterranean region. Biological diversity in space and time. Oxford University Press, New York

Breslow NE, Clayton DG (1993) Approximate inference in generalized linear mixed models. J Am Stat Assoc 88(421):9-25

Burnham KP, Anderson DR (2002) Model selection and multimodel inference, 2nd edn. Springer, New York

Campos P (2004) Towards a sustainable global economics approach for Mediterranean agroforestry systems. In: Schnabel S, Ferreira A (eds) Sustainability of agrosilvopastoral systems. Advances in geoecology. Catena Verlag, Reiskirchen, pp 13-28

Castro H, Freitas H (2009) Above-ground biomass and productivity in the Montado: from herbaceous to shrub dominated communities. J Arid Environ 73(4-5):506-511

Chatterjee S, Price B (1991) Regression analysis by example, 2nd edn. Wiley, New York

Donald PF, Evans AD (2006) Habitat connectivity and matrix restoration: the wider implications of agrienvironment schemes. J Appl Ecol 43(2):209-218

Donald PF, Pisano G, Rayment MD, Pain DJ (2002) The Common Agricultural Policy, EU enlargement and the conservation of Europe's farmland birds. Agric Ecosyst Environ 89(3):167-182

Doncaster CP, Rondinini C, Johnson PCD (2001) Field test for environmental correlates of dispersal in hedgehogs Erinaceus europaeus. Ecology 70:33-46

Eccard JA, Walther RB, Milton SJ (2000) How livestock grazing affects vegetation structure and small mammal distribution in the semi-arid Karoo. J Arid Environ 46(2):103-106

Fahrig L, Rytwinski T (2009) Effects of roads on animal abundance: an empirical review and synthesis. Ecol Soc 14(1):21. http://www.ecologyandsociety.org/vol14/iss1/art21/. Accessed 10 Feb 2012

Ferreira DB (2000) Environmental impact of land use change in the inner Alentejo (Portugal) in the 20th century. In: Slaymaker O (ed) Geomorphology and human activity: their role in global environmental change. Wiley, Chichester, pp 249-267 
Fitzgibbon CD (1997) Small mammals in farm woodlands: the effects of habitat, isolation and surrounding land-use patterns. J Appl Ecol 34(2):530-539

Forman RTT, Alexander LE (1998) Roads and their major ecological effects. Annu Rev Ecol Syst 29(1):207-231

Gaspar P, Mesías FJ, Escribano M, Rodriguez de Ledesma A, Pulido F (2007) Economic and management characterization of dehesa farms: implications for their sustainability. Agrofor Syst 71(3):151-162

Gelling M, Macdonald DW, Mathews F (2007) Are hedgerows the route to increased farmland small mammal density? Use of hedgerows in British pastoral habitats. Landsc Ecol 22(7):1019-1032

Gibson CWD, Brown VK, Losito L, McGavin GC (1992) The response of invertebrate assemblies to grazing. Ecography 15(2):166-176

Golley FB (1960) Energy dynamics of a food chain of an old-field community. Ecol Monogr 30(2):187-206

Gómez JM, Puerta-Piñero C, Schupp EW (2008) Effectiveness of rodents as local seed dispersers of holm oaks. Oecologia 155(3):529-537

Gonçalves P, Alcobia S, Simões L, Santos-Reis M (2011) Effects of management options on mammal richness in a Mediterranean agro-silvo-pastoral system. Agrofor Syst 85(3):383-395

Graham MH (2003) Confronting multicollinearity in ecological multiple regression. Ecology 84(11): 2809-2815

Grilo C, Bissonette J, Santos-Reis M (2009) Spatial-temporal patterns in Mediterranean carnivore road casualties: consequences for mitigation. Biol Conserv 142:301-313

Hanski I, Henttonen H, Korpimäki E, Oksanen L, Turchin P (2001) Small-rodent dynamics and predation. Ecology 82(6):1505-1520

Hayward B, Heske EJ, Painter CW (1997) Effects of livestock grazing on small mammals at a desert cienaga. J Wildl Manag 61(1):123-129

Holm S (1979) A simple sequentially rejective multiple test procedure. Scand J Stat 6(December 1977):65-70

Hope ACA (1968) A simplified Monte Carlo significance test procedure. J R Stat Soc B 30(3):582-598

Hopwood JL (2008) The contribution of roadside grassland restorations to native bee conservation. Biol Conserv 141(10):2632-2640

Huijser MP, Clevenger AP (2006) Habitat and corridor function of rights-of-way. In: Davenport J, Davenport JL (eds) The ecology of transportation: managing mobility for the environment. Springer, Dordrecht, The Netherlands, pp 233-254

Ibáñez J, Martínez J, Schnabel S (2007) Desertification due to overgrazing in a dynamic commercial livestock-grass-soil system. Ecol Model 205(3-4):277-288

Kleijn D, Sutherland WJ (2003) How effective are European agri-environment schemes in conserving and promoting biodiversity? J Appl Ecol 40(6):947-969

Korpimaki E, Norrdahl K (1991) Numerical and functional responses of kestrels, short-eared owls, and longeared owls to vole densities. Ecology 72:814-826

Kotler BP (1997) Patch use by gerbils in a risky environment: manipulating food and safety to test four models. Oikos 78(2):274-282

Longland WS, Price MV (1991) Direct observations of owls and heteromyid rodents: can predation risk explain microhabitat use? Ecology 72(6):2261-2273

Meeus JHA (1993) The transformation of agricultural landscapes in Western Europe. Sci Total Environ 129(1-2):171-190

Mendiburu Fd (2010) Statistical procedures for agricultural research. R package version 109. http://CRANRprojectorg/package=agricolae. Accessed 1 Jan 2012

Meunier FD, Corbin J, Verheyden C, Jouventin P (1999) Effects of landscape type and extensive management on use of motorway roadsides by small mammals. Can J Zool 77(1):108-117

Meunier FD, Verheyden C, Jouventin P (2000) Use of roadsides by diurnal raptors in agricultural landscapes. Biol Conserv 92(3):291-298

Milchunas DG, Lauenroth WK, Burke IC (1998) Livestock grazing: animal and plant biodiversity of shortgrass steppe and the relationship to ecosystem function. Oikos 83(1):65-74

Moleón M, Gil-Sánchez JM (2003) Food habits of the wildcat (Felis silvestris) in a peculiar habitat: the Mediterranean high mountain. J Zool 260(01):17-22

Montgomery SSJ, Montgomery WI (1990) Intrapopulation variation in the diet of the wood mouse Apodemus sylvaticus. J Zool 222(4):641-651

Moran MD (2003) Arguments for rejecting the sequential Bonferroni in ecological studies. Oikos 100(2): 403-405

Moreno G, Pulido FJ (2008) The functioning, management and persistence of dehesas. In: Rigueiro-Rodróguez A, McAdam J, Mosquera-Losada MR (eds) Agroforestry in Europe. Current status and future prospects. Advances in agroforestry, vol 6. Springer, Dordrecht, pp 127-160 
Mortelliti A, Boitani L (2008) Interaction of food resources and landscape structure in determining the probability of patch use by carnivores in fragmented landscapes. Landsc Ecol 23(3):285-298

Muñoz A, Bonal R, Díaz M (2009) Ungulates, rodents, shrubs: interactions in a diverse Mediterranean ecosystem. Basic Appl Ecol 10(2):151-160

Myers N, Mittermeier RA, Mittermeier CG, da Fonseca GAB, Kent J (2000) Biodiversity hotspots for conservation priorities. Nature 403(6772):853-858

Noordijk J, Raemakers IP, Schaffers AP, Sýkora KV (2009) Arthropod richness in roadside verges in the Netherlands. Terr Arthr Rev 2:63-76

Oxley DJ, Fenton MB, Carmody GR (1974) The effects of roads on populations of small mammals. J Appl Ecol 11(1):51-59

Pinto-Correia T, Mascarenhas J (1999) Contribution to the extensification/intensification debate: new trends in the Portuguese montado. Landsc Urban Plan 46(1-3):125-131

Puerto A, Rico M, Matias MD, Garcia JA (1990) Variation in structure and diversity in Mediterranean grasslands related to trophic status and grazing intensity. J Veg Sci 1(4):445-452

R Development Core Team (2010) R: a language and environment for statistical computing. R. Foundation for Statistical Computing, Vienna

Ramp D, Caldwell J, Edwards K, Warton D, Croft D (2005) Modelling of wildlife fatality hotspots along the Snowy Mountain Highway in New South Wales, Australia. Biol Conserv 126:474-490

Reino L, Porto M, Morgado R, Moreira F, Fabião A, Santana J, Delgado A, Gordinho L, Cal J, Beja P (2010) Effects of changed grazing regimes and habitat fragmentation on Mediterranean grassland birds. Agric Ecosyst Environ 138(1-2):27-34

Rodríguez C, Peris SJ (2007) Habitat associations of small mammals in farmed landscapes: implications for agri-environmental schemes. Anim Biol 57(3):301-314

Rosalino LM, Ferreira D, Leitão I, Santos-Reis M (2011) Usage patterns of Mediterranean agro-forest habitat components by wood mice Apodemus sylvaticus. Mamm Biol 76(3):268-273

Saarinen K, Valtonen A, Jantunen J, Saarnio S (2005) Butterflies and diurnal moths along road verges: does road type affect diversity and abundance? Biol Conserv 123(3):403-412

Sabino-Marques H, Mira A (2011) Living on the verge: are roads a more suitable refuge for small mammals than streams in mediterranean pastureland? Ecol Res 26(2):1-11

Santos SM, Mathias M, Mira A, Simoes MP (2007) Vegetation structure and composition of road verge and meadow sites colonized by Cabrera vole (Microrus cabrerae Thomas). Pol J Ecol 55(3):481-493

Sarmento P (1996) Feeding ecology of the European wildcat Felis silvestris in Portugal. Acta Theriol 41:409-414

Searle JB (1985) Methods for determining the sex of common shrews (Sorex araneus). J Zool 206:279-282

Stoate C, Boatman ND, Borralho RJ, Carvalho C, Snoo GR, Eden P (2001) Ecological impacts of arable intensification in Europe. J Environ Manag 63(4):337-365

Tanghe M, Godefroid S (2000) Road verge grasslands in southern Belgium and their conservation value. Fragm Florist Geobot 45:147-163

Tattersall FH, Macdonald DW, Hart BJ, Johnson P, Manley W, Feber R (2002) Is habitat linearity important for small mammal communities on farmland? J Appl Ecol 39(4):643-652

Todd IA, Tew TE, Macdonald DW (2000) Arable habitat use by wood mice (Apodemus sylvaticus). 1. Macrohabitat. J Zool 250(3):299-303

Torre I, Díaz M, Martínez-Padilla J, Bonal R, Viñuela J, Fargallo JA (2007) Cattle grazing, raptor abundance and small mammal communities in Mediterranean grasslands. Basic Appl Ecol 8(6):565-575

Tshiguvho TE, Dean WRJ, Robertson HG (1999) Conservation value of road verges in the semi-arid Karoo, South Africa: ants (Hymenoptera: Formicidae) as bio-indicators. Biodivers Conserv 8(12):1683-1695

Virgós E, Llorente M, Cortés Y (1999) Geographical variation in genet (Genetta genetta L.) diet: a literature review. Mamm Rev 29(2):117-126

Watts CHS (1968) The foods eaten by wood mice (Apodemus sylvaticus) and bank voles (Clethrionomys glareolus) in Wytham Woods, Berkshire. J Anim Ecol 37(1):25-41

Way JM (1977) Roadside verges and conservation in Britain: a review. Biol Conserv 12(1):65-74

Whittingham MJ (2007) Will agri-environment schemes deliver substantial biodiversity gain, and if not why not? J Appl Ecol 44(1):1-5 